\title{
Micro-Oxygenation and Fining Agent Treatments: Impact on Color of Moroccan Red Press Wine
}

\author{
Mohamed Ben Aziz ${ }^{1,2}$, Laetitia Mouls ${ }^{3}$, Hélène Fulcrand ${ }^{3}$ and Hassan Hajjaj ${ }^{*}$ \\ ${ }^{1}$ Laboratory of Plant Biotechnology and Molecular Biology Faculty of Sciences, Meknès, Moulay Ismail University, BP 11201, Zitoune Avenue, Meknes, Morocco \\ ${ }^{2}$ Company Les Celliers de Meknès, Morocco \\ ${ }^{3}$ INRA, Montpellier SupAgro, Montpellier University, UMR1083, SPO, F-34060 Montpellier, France
}

Correspondence to:

Hassan Hajjaj

Laboratory of Plant Biotechnology and

Molecular Biology Faculty of Sciences

Meknès, Moulay Ismail University

BP 11201, Zitoune Avenue, Meknes, Morocco

Tel: 00212671380696

Fax: 00212535454301

E-mail: h_hajjaj@yahoo.com

Received: November 25, 2016

Accepted: March 07, 2017

Published: March 10, 2017

Citation: Aziz MB, Mouls L, Fulcrand H, Hajjaj H. 2017. Micro-Oxygenation and Fining Agent Treatments: Impact on Color of Moroccan Red Press Wine. J Food Chem Nanotechnol 3(1): 38-43.

Copyright: (C) 2017 Aziz et al. This is an Open Access article distributed under the terms of the Creative Commons Attribution 4.0 International License (CC-BY) (http://creativecommons. org/licenses/by/4.0/) which permits commercial use, including reproduction, adaptation, and distribution of the article provided the original author and source are credited.

Published by United Scientific Group

\begin{abstract}
Red press wine is collected after pressing solid parts (seed and skin) of grapes pomaces. Higher pressure induces more colorful, astringent, bitter and rustic wines. This is caused by the presence of undesirable phenolic compounds. To overcome this problem, the most common practice used in wine industry is the oenological treatment which enhances the clarity, stability and the wine taste. In the present work, press wines were separately submitted to four different treatments: micro-oxygenation and the addition of three fining agents: gelatin, polyvinylpolypyrrolidone (PVPP) and pea protein. The phenolic total index decreased $(8 \%)$ significantly $(\mathrm{P}<0.05)$ for gelatin treatment, the PVPP based formulation treatment led to the largest loss $(8 \%)$ in color intensity, (12\%) in redness $\left(\mathrm{a}^{*}\right),(9 \%)$ in polymeric pigments and increasing to $9 \%$ lightness $\left(\mathrm{L}^{*}\right)$. Unlike micro-oxygenation which has decreased (5\%) the color intensity. For the monomeric anthocyanins, the greatest reduction of acylated and coumaroylated anthocyanins at bottling and glucoside anthocyanidins after five months of storage was observed for both basic PVPP and gelatin.
\end{abstract}

\section{Keywords} intensity

Red press wine, Micro-oxygenation, Fining agents, Anthocyanins, Color

\section{Introduction}

During red wine making, the color stabilization is a real key step. Indeed, extracting a maximum of color and a sufficient amount of tannins to stabilize it and provide body to the wines is quite an art [1]. Anthocyanins and their derivatives are the crucial pigments responsible for the red wine color. During wine aging, the concentration of monomeric anthocyanins declines constantly, while numerous more complex and stable anthocyanin derived pigments are formed [2]. It is usually supposed that these pigments are formed by direct condensation between anthocyanin and/or flavan-3-ols or by a aldehyde-mediated condensation resulting in oligomeric and polymeric pigments, sometimes referred to as pigmented polymers. Some authors have shown that anthocyanins can react as well with metabolites of the two successive fermentations including pyruvic acid, vinylphenol, glyoxylic acid, giving rise to a new family of anthocyaninderived pigments, namely, pyrano-anthocyanins [2-4]. The color of wine is mainly assessed by spectrophotometric measurements that are converted into typical indexes claimed to reflect the composition and concentration of anthocyanins and polymeric pigments. The color evolution is influenced by several factors, including yeast metabolites, oxygen exposure and storage time [5]. In young red wines the original anthocyanins (also called monomeric anthocyanins in 
opposition to polymeric anthocyanins) occur predominantly in a dynamic equilibrium among five major molecular forms, including the bisulfite addition flavene compound, the quinoidal base, the flavylium cation, the semimetal or carbinol pseudobase and the chalcone (cis and trans forms) [6]. The monomeric anthocyanin molecules are not very stable, so their concentration in wine decreases within the first few months of barrel aging. Despite the total apparent disappearance of monomeric anthocyanins (which occurs within few years), the wine keeps the red color which is due to combination reactions of monomeric anthocyanins with various compounds in the wine, especially tannins. The resulting structures are not very well characterized [7]. The red press wine is elaborated from the pressing of grape pomace after the maceration. It often presents some characteristic qualities like to be rich on phenolic compounds and colors than running wine. It can also give roundness, volume and structures to running wine at blinding step and it is used to increase the color of less colorful and tannic wine $[8,9]$. The soft and fruit taste of wine are masked by press wine in the other hand. That is why the press wines are treated by oenological treatments (fining, microoxygenation) before the blinding with running wine [8]. In the practice, it is of great importance to obtain a good color and clearness of wines and to possibly keep them for a prolonged period. Fining agents are applied to obtain limpid and bright wines, they are intended to achieve clarity and improve color, flavor, and physical stability of wine, and they should serve to remove only the components that make wine unstable. The fining agents such as PVPP, gelatin, egg albumin and casein demonstrated reduction of phenolic levels and altered the color in some wines [10]. The use of plant-derived proteins as wine fining agents has become of much interest [11]. Micro-oxygenation is a technique that consists of introducing small and measured amounts of oxygen into wines with the objective of improving wine color characteristics and stability, aroma and texture [12]. The oxygen leads to different chemical reactions anthocyanins and tannins. All of these events result in the formation of more stable compounds that stabilize wine color since they partly resist discoloration by $\mathrm{SO}_{2}$ and provide better color stability at wine $\mathrm{pH}[13,14]$. The main objectives of this work were to compare the impact of micro-oxygenation and of three types of fining agents (gelatin, PVPP-formulation and pea protein) on the chromatic characteristics and pigment composition of the red press wines after treatment, at bottling and after five months of storage on the basis of absorbance measurements and liquid chromatography on line with UVvisible detection.

\section{Materials and Methods}

\section{Winemaking}

In 2015 vintage: after the end of the alcoholic fermentation, the grape pomace of grapes Vitis vinifera var of Cabernet-Sauvignon is pressed with pressure degrees varying from 0 to 300 mbars in the cellar Château Rôslane. At the end of pressing, the wine is treated with clarification enzyme, centrifuged at $8000 \mathrm{tr} / \mathrm{min}$ and distributed on four tanks of 10 hectoliters, one called control $\left(\mathrm{T}_{0}\right)$ and the others treated with some commercial fining agents: Pork liquid gelatin $\left(\mathrm{T}_{2}\right)$ at a concentration of $0.6 \mathrm{~mL} / \mathrm{L}, \mathrm{PVPP}$ coupled with bentonite $\left(\mathrm{T}_{3}\right)$ (dose $0.8 \mathrm{~g} / \mathrm{L}$, powders) and formulation of pea protein bentoniteand polysaccharides $\left(\mathrm{T}_{4}\right)$ (dose $0.8 \mathrm{~g} / \mathrm{L}$, powders). Another tank of 25 hectoliters was used for micro-oxygenation trial $\left(\mathrm{T}_{1}\right)$, the air being delivered at $60 \mathrm{~mL} / \mathrm{L} / \mathrm{month}$ until the beginning of malolactic fermentation. Five months after the end of alcoholic fermentation, the samples were stored in bottles of $750 \mathrm{~mL}$ and analyzed [15].

\section{Analysis}

\section{Chromatic characteristics}

In this work we used the same chromatic measurement procedure described in the previous work $[2,16]$. Absorbance measurements were made with a SAFAS UV mc2 spectrophotometer (Monaco) and color indices were deduced from these absorbance measurements. All the absorbance measurements were converted to a $10 \mathrm{~mm}$ light path cell and a dilution of 1 before calculating the indices. Absorbance values at 420, 520 and $620 \mathrm{~nm}$ were measured, $30 \mathrm{~min}$ after the addition of acetaldehyde, in a $1 \mathrm{~mm}$ light path cell. Hue was calculated as $A_{420 \mathrm{~nm}} / A_{520 \mathrm{~nm}}$ and color intensity (CI) as $A_{420 \mathrm{~nm}}+A_{520 \mathrm{~nm}}+A_{620 \mathrm{~nm}}$, yellow $\left(\mathrm{A}_{420 \%}\right)$, red $\left(\mathrm{A}_{520 \%}\right)$ and blue color intensity $\left(\mathrm{A}_{620 \%}\right)$ according to Glories [16] are: $\mathrm{A}_{420 \%}=$ $\left(\mathrm{A}_{420} / \mathrm{CI}\right)^{*} 100, \mathrm{~A}_{520 \%}=\left(\mathrm{A}_{520} / \mathrm{CI}\right)^{*} 100$ and $\mathrm{A}_{620 \%}=\left(\mathrm{A}_{620} / \mathrm{CI}\right)^{* 100}$. Wine pigments corrected of bisulphite at wine $\mathrm{pH}(\mathrm{PV})$ was defined as the absorbance at $520 \mathrm{~nm}, 30 \mathrm{~min}$ after addition of acetaldehyde. Color due to derivatives resistant to sulphite bleaching was determined at $520 \mathrm{~nm}$ in a $1 \mathrm{~mm}$ light path cell, $30 \mathrm{~min}$ after addition of a metabisulphite solution. Sulphites bleaching resistant pigments $\left(\mathrm{PRSO}_{2}\right)$ were then calculated. Total pigments at acidic $\mathrm{pH}(\mathrm{PpH}<1)$ was determined from absorbance at $520 \mathrm{~nm}$ with a $10 \mathrm{~mm}$ light path, $4 \mathrm{~h}$ after a 100 fold dilution in $\mathrm{HCl} 1 \mathrm{M}$. The CIELab chromatic characteristics $\mathrm{L}^{*}$ (lightness), a* (measure of redness) and $b^{*}$ (measure of yellowness) were determined directly by the software incorporated in spectrophotometer Konica Minolta apparatus (Japan).

Phenolic compounds

$\mathrm{PTI}_{280 \mathrm{~nm}}$, which estimates total phenol content, was determined according to the method described by RibéreauGayon et al. [7]. Total anthocyanins were determined by spectrophotometry of wine diluted with ethanol and hydrochloric acid, making a reading of an aliquot with water $\left(\mathrm{A}_{520 \mathrm{~nm}}\right)$. Another type treated with $\mathrm{NaHSO}_{3}\left(\mathrm{~A}_{520 \mathrm{~nm}}\right)$, the formula is as follows: $[\mathrm{Ant}]=\left(\mathrm{A}_{520 \mathrm{~nm}}-\mathrm{A}_{520 \mathrm{~nm}}\right) * 875$ [17]. Polymeric pigments $(\mathrm{PP})$ corresponded to pigments resistant to $\mathrm{SO}_{2}$ bleaching and were estimated according to Glories [16]. Two samples were prepared to calculate $\mathrm{IC}\left(\mathrm{SO}_{2}\right)$ and $\mathrm{IC}\left(\mathrm{H}_{2} \mathrm{O}\right)$. The first one was prepared as follows: $0.5 \mathrm{~mL}$ of wine, $4.5 \mathrm{~mL}$ of model wine (12\% ethanol, 1.5 g.L. - $^{-1}$ tartaric acid and $\mathrm{pH}=$ 3.2), and $20 \mu \mathrm{L}$ of $\mathrm{Na}_{2} \mathrm{SO}_{3}$. After $5 \mathrm{~min}$, absorbance at 420 and $520 \mathrm{~nm}$ were read under $10 \mathrm{~mm}$ optical way: $\mathrm{IC}\left(\mathrm{SO}_{2}\right)=$ $\mathrm{A}_{420 \mathrm{~nm}}+\mathrm{A}_{520 \mathrm{~nm}}$. The second one was prepared as follows: $0.5 \mathrm{~mL}$ of wine, $4.5 \mathrm{~mL}$ of model wine, and $20 \mu \mathrm{L}$ of water; $\mathrm{IC}\left(\mathrm{SO}_{2}\right)$ $=\mathrm{A}_{420 \mathrm{~nm}}+\mathrm{A}_{520 \mathrm{~nm}} \cdot \mathrm{PP}=\mathrm{IC}\left(\mathrm{SO}_{2}\right) / \mathrm{IC}\left(\mathrm{H}_{2} \mathrm{O}\right)$ [18]. In this work we used the same procedure for the HPLC analyses previously described by Ducasse [18]. Monomeric anthocyanins were 
analyzed by direct injection of wine samples into the HPLC system. HPLC-DAD analyses were performed using a Waters 2690 system equipped with an auto-sampler system, a Waters 996 photodiode array detector, and Millennium 32 chromatography manager software (Waters, Milford, MA). Separation was achieved on a reversed-phase Atlantis dC18 column $(250 \times 2.1 \mathrm{~mm}$ i.d., $5 \mu \mathrm{m}$ packing $)$ protected with a guard column of the same material $(20 \times 2.1 \mathrm{~mm}$ i.d., $3 \mu \mathrm{m}$ packing) (Waters, Milford, MA). The elution conditions were as follows: $0.250 \mathrm{~mL} / \mathrm{min}$ flow rate; oven temperature $30{ }^{\circ} \mathrm{C}$; solvent A: water/formic acid $(95 / 5 \mathrm{v} / \mathrm{v})$; solvent B: acetonitrile/ water/formic acid $(80 / 15 / 5 \mathrm{v} / \mathrm{v} / \mathrm{v})$; elution began isocratically with $0 \% \mathrm{~B}$ during $5 \mathrm{~min}$, then continued with linear gradients from $0 \%$ to $10 \%$ B for $20 \mathrm{~min}, 10 \%$ to $20 \%$ B for $15 \mathrm{~min}, 20 \%$ to $45 \% \mathrm{~B}$ for $15 \mathrm{~min}, 45 \%$ to $60 \% \mathrm{~B}$ for $15 \mathrm{~min}, 60 \%$ to $80 \%$ $\mathrm{B}$ for $5 \mathrm{~min}$, followed by washing and re-equilibration of the column.

\section{Sensorial analysis}

The sensory evaluations of different samples of press wine were performed by a panel of five professional judges. The panel test was planned to compare the effect of four oenological treatments on color intensity of the corresponding red press wines after treatment at bottling and after five months of storage (before blinding with running wine). The scoring scale was from 1 to 6 .

\section{Statistical data analysis}

The data are presented as means $\pm \mathrm{SD}$. The statistical calculations used are Analysis of variance one factor and the least significant difference (LSD) according to StudentNewman-Keuls. The five samples at bottling and after five months were compared to separate the means, and significance was accepted at the $5 \%$ level comparison of treatment means (LSD, 5\% level). The statistical treatment was done using SPSS 17 statistics software.

\section{Results and Discussion}

\section{Chromatic characteristics and sensorial analysis}

According to Table 1, we showed the impact of the micro-oxygenation and fining agents on changes of chromatic characteristics of Cabernet-Sauvignon press wine. At bottling, it clearly showed that fining treatments (gelatin $\left(\mathrm{T}_{2}\right)$, PVPP based formulation $\left(\mathrm{T}_{3}\right)$ and pea protein $\left(\mathrm{T}_{4}\right)$ ) reduced significantly the $\mathrm{PTI}_{280 \mathrm{~nm}}$, color intensity $(\mathrm{CI})$, intensity of red color $\left(\mathrm{A}_{520 \%}\right)$, redness $\left(\mathrm{a}^{*}\right)$, yellowness compound $\left(\mathrm{b}^{*}\right)$ and increased the lightness $\left(\mathrm{L}^{*}\right)$. The latter is distinct from PVPP based formulation $\left(\mathrm{T}_{3}\right)(11 \%)$. The color intensity $(\mathrm{CI})$ of press wine was significantly increased $(5 \%)$ by micro-oxygenation treatment $\left(\mathrm{T}_{1}\right)$ compared to the control $\left(\mathrm{T}_{0}\right)$. The significant increase of hue intensity by all treatments indicated that red and blue color participation in wine are decreased, unlike yellow color which was increased. The CIELab method proved that in each fined wine, lightness $\left(\mathrm{L}^{*}\right)$ increased significantly, which seemed to be correlated with less redness $\left(a^{*}\right)$, due to the removal of pigments [19]. This data are in accordance with the results obtained from polymeric pigments (Figure 1). After five months in the bottle, a further decrease in $A_{520 \%}$, $a^{*}$ and $L^{*}$ were observed in all samples, the same happened for the color intensity $(\mathrm{CI})$ except $\mathrm{T}_{4}$ treatment. In addition, an increase in yellow $\left(\mathrm{A}_{420 \%}\right)$, blue $\left(\mathrm{A}_{620 \%}\right)$, hue and yellowness compounds $\left(b^{*}\right)$ were also observed in all samples. The observed differences at bottling step between samples were not maintained after five months of storage. The phenolic total index $\left(\mathrm{PTI}_{280 \mathrm{~nm}}\right)$ was significantly lowered by adding fining agents $\left(\mathrm{T}_{2}, \mathrm{~T}_{3}\right.$ and $\left.\mathrm{T}_{4}\right)$. In general, gelatin $\mathrm{T}_{2}$ was the most fining agent that decreased the $\mathrm{PTI}_{280 \mathrm{~nm}}$. Owing to the capacity of the polyphenol compounds to establish hydrogen bonds with proteins, a part of the polyphenolic fraction is probably removed during the fining treatments [20]. The micro-oxygenation treatment $\left(T_{1}\right)$ led to a significant increase of both colors (red and blue intensities), redness $\left(\mathrm{b}^{*}\right)$ and the color intensity (CI) compared to the control $\left(\mathrm{T}_{0}\right)$. This rise of color intensity can be mostly attributed to an increase of free anthocyanins coming from the colorless anthocyanin bisulfite adducts [21]. The oxygen played an important role in the different processes that took place during winemaking process and the ageing of wine. It had an influence on the phenolic composition and indirectly affected the wine color [12]. Pea protein $\left(\mathrm{T}_{4}\right)$ led to more lightness $\left(\mathrm{L}^{*}\right)$ and the yellow compound $\left(\mathrm{b}^{*}\right)$ increased after storage. As illustrated on the Figure 2, all pigments are represented by the total pigments at acidic $\mathrm{pH}$ parameter $(\mathrm{PpH}<1)$. The latter is converted to a value 100 to estimate the percentage of both pigments $\mathrm{PV}$ (wine pigments at wine $\mathrm{pH}$ ) and $\mathrm{PRSO}_{2}$ (the pigments resistant to discoloration). For all the studied samples, the parameters proportion $\left(\mathrm{PpH}<1, \mathrm{PV}, \mathrm{PRSO}_{2}\right)$ evolved between the bottling step and the five months of storage. At bottling, the PV contributed to an average of $48 \%$ in all the five samples. After five months, the PV increased to an average of $73 \%$. The highest values of PV at bottling and after five months were due to PVPP based formulation treatment $\left(\mathrm{T}_{3}\right)$. The press wine contained polyphenols, which include essentially anthocyanins, proanthocyanidins, phenolic acids, and new derived pigments generated from polyphenols during winemaking and the ageing process. Some of these new phenolic compounds are more stable pigments than free anthocyanins and enable to stabilize the color of the press wine $[7,8]$. The increases of $\mathrm{PV}$ and $\mathrm{PRSO}_{2}$ observed after five months of storage showed the existence of reactions between anthocyanins and/or other co-pigment. These reactions released more complex and stable anthocyanin derived pigments, such as various pyranoanthocyanins, polymeric anthocyanins produced from condensation between anthocyanin and/or flavan-3-ols directly or mediated by aldehydes. Such variations can result in the significant changes of the color $[2,8,22]$. The monitoring of total anthocyanins and the polymeric pigments parameter during the storage (Figure 2) showed a drop of total anthocyanins, and an increase of polymerized pigments. However, the control wine maintained a greater amount of total anthocyanins compared to the treated wines after five months. These results are due to the breakdown and/or the reactions of a part of anthocyanins with other molecules [7, 8]. The anthocyanins and large phenols, such as polymerized anthocyanins, are preferentially removed by fining agents. During five months, the greatest loss of total anthocyanins and polymerized pigments was observed by gelatin $\left(\mathrm{T}_{2}\right)$ and pea protein based formulation $\left(\mathrm{T}_{4}\right)$ fining treatment respectively. 


\begin{tabular}{|c|c|c|c|c|c|c|c|c|c|c|c|c|}
\hline Parameters & Sig & $\mathrm{T}_{0}$ & $\mathrm{~T}_{1}$ & $\mathrm{~T}_{2}$ & $\mathrm{~T}_{3}$ & \multirow[t]{2}{*}{$\mathrm{T}_{4}$} & \multirow[t]{2}{*}{ Sig } & \multirow[t]{2}{*}{$\mathrm{T}_{0}$} & \multirow{2}{*}{$\begin{array}{l}\mathrm{T}_{1} \\
5 \text { months }\end{array}$} & \multirow[t]{2}{*}{$\mathrm{T}_{2}$} & \multirow[t]{2}{*}{$\mathrm{T}_{3}$} & \multirow[t]{2}{*}{$\mathrm{T}_{4}$} \\
\hline Month & & & \multicolumn{3}{|l|}{ At bottling } & & & & & & & \\
\hline $\mathrm{PTI}_{280 \mathrm{~nm}}$ & ** & $97.01 \pm 0.04^{c}$ & $97.01 \pm 0.05^{c}$ & $89.00 \pm 0.05^{\mathrm{a}}$ & $89.02 \pm 0.04^{\mathrm{a}}$ & $92.01 \pm 0,05^{b}$ & $*$ & $99.12 \pm 0.0^{c}$ & $104.95 \pm 0.0^{\mathrm{d}}$ & $90.17 \pm 0.07^{\mathrm{a}}$ & $92.3 \pm 0.2^{\mathrm{b}}$ & $90.33 \pm 0.1^{\mathrm{a}}$ \\
\hline D420 (\%) & n.s & $32.74 \pm 1^{a}$ & $33.91 \pm 0.1^{\mathrm{a}}$ & $34.74 \pm 0.6^{\mathrm{a}}$ & $35.08 \pm 0.1^{\mathrm{a}}$ & $35.70 \pm 1^{a}$ & $* *$ & $42.15 \pm 0.4^{b}$ & $38.6 \pm 0.5^{\mathrm{a}}$ & $43.3 \pm 0.4^{c}$ & $44.0 \pm 0.1^{\mathrm{c}}$ & $42.5 \pm 0.1^{\mathrm{b}}$ \\
\hline D520 (\%) & * & $53.31 \pm 1.2^{\mathrm{b}}$ & $51.67 \pm 0.1^{1 \mathrm{~b}}$ & $49.98 \pm 0.1^{\mathrm{a}}$ & $50.94 \pm 0.4^{a}$ & $50.41 \pm 0.6^{a}$ & $* *$ & $41.15 \pm 0.04^{a}$ & $44.66 \pm 0.1^{b}$ & $41.49 \pm 0.1^{\mathrm{a}}$ & $41.43 \pm 0.6^{a}$ & $42.06 \pm 0.3^{\mathrm{a}}$ \\
\hline D620 (\%) & n.s & $13.94 \pm 0.2^{\mathrm{a}}$ & $14.43 \pm 0.1^{\mathrm{a}}$ & $15.28 \pm 0.7^{a}$ & $13.99 \pm 0.5^{\mathrm{a}}$ & $13.89 \pm 0.4^{\mathrm{a}}$ & $* *$ & $16.67 \pm 0.3^{b}$ & $16.75 \pm 0.6^{\mathrm{b}}$ & $15.25 \pm 0.3^{\mathrm{ab}}$ & $14.65 \pm 0.7^{\mathrm{a}}$ & $14.24 \pm 0.2^{\mathrm{a}}$ \\
\hline CI & ** & $16.77 \pm 0.3^{b}$ & $17.71 \pm 0.1^{\mathrm{c}}$ & $14.77 \pm 0.1^{\mathrm{a}}$ & $14.34 \pm 0.2^{\mathrm{a}}$ & $14.76 \pm 0.2^{\mathrm{a}}$ & $* *$ & $14.93 \pm 0.2^{\mathrm{b}}$ & $15.6 \pm 0.04^{c}$ & $14.1 \pm 0.1^{\mathrm{a}}$ & $14.0 \pm 0.1^{\mathrm{a}}$ & $15.01 \pm 0.2^{b}$ \\
\hline Hue & * & $0.61 \pm 0.0^{\mathrm{a}}$ & $0.66 \pm 0.0^{0 \mathrm{ab}}$ & $0.70 \pm 0.0^{\mathrm{b}}$ & $0.69 \pm 0.0^{\mathrm{b}}$ & $0.71 \pm 0.0^{b}$ & * & $1.0 \pm 0.01^{\mathrm{ab}}$ & $0.9 \pm 0.01^{\mathrm{a}}$ & $1.0 \pm 0.01^{\mathrm{b}}$ & $1.1 \pm 0.01^{\mathrm{b}}$ & $1.0 \pm 0.01^{\mathrm{ab}}$ \\
\hline $\mathrm{L}^{*}(\%)$ & ** & $56.23 \pm 0.1^{\mathrm{a}}$ & $56.06 \pm 0.1^{\mathrm{a}}$ & $60.70 \pm 0.1^{\mathrm{d}}$ & $62.48 \pm 0.1^{\mathrm{c}}$ & $61.18 \pm 0.1^{\mathrm{b}}$ & $* *$ & $48.07 \pm 0.1^{\mathrm{a}}$ & $50.25 \pm 0.1^{\mathrm{c}}$ & $50.06 \pm 0.1^{\mathrm{c}}$ & $48.5 \pm 0.1^{\mathrm{b}}$ & $55.55 \pm 0.1^{\mathrm{d}}$ \\
\hline $\mathrm{a}^{*}$ & $* *$ & $40.70 \pm 0.1^{\mathrm{d}}$ & $40.51 \pm 0.1^{\mathrm{d}}$ & $37.86 \pm 0.1^{\mathrm{c}}$ & $35.64 \pm 0.1^{\mathrm{a}}$ & $36.58 \pm 0.1^{b}$ & $* *$ & $30.27 \pm 0.1^{\mathrm{c}}$ & $31.53 \pm 0.1^{\mathrm{d}}$ & $29.34 \pm 0.1^{\mathrm{b}}$ & $26.39 \pm 0.1^{a}$ & $30.77 \pm 0.1^{\mathrm{c}}$ \\
\hline $\mathbf{b}^{*}$ & $* *$ & $2.56 \pm 0.1^{\mathrm{c}}$ & $1.78 \pm 0.1^{\mathrm{a}}$ & $2.47 \pm 0.1^{\mathrm{c}}$ & $2.23 \pm 0.1^{\mathrm{b}}$ & $1.84 \pm 0.1^{\mathrm{a}}$ & $* *$ & $3.61 \pm 0.1^{\mathrm{b}}$ & $4.19 \pm 0.1^{\mathrm{c}}$ & $3.89 \pm 0.1^{\mathrm{b}}$ & $2.88 \pm 0.1^{\mathrm{a}}$ & $5.95 \pm 0.1^{\mathrm{d}}$ \\
\hline
\end{tabular}
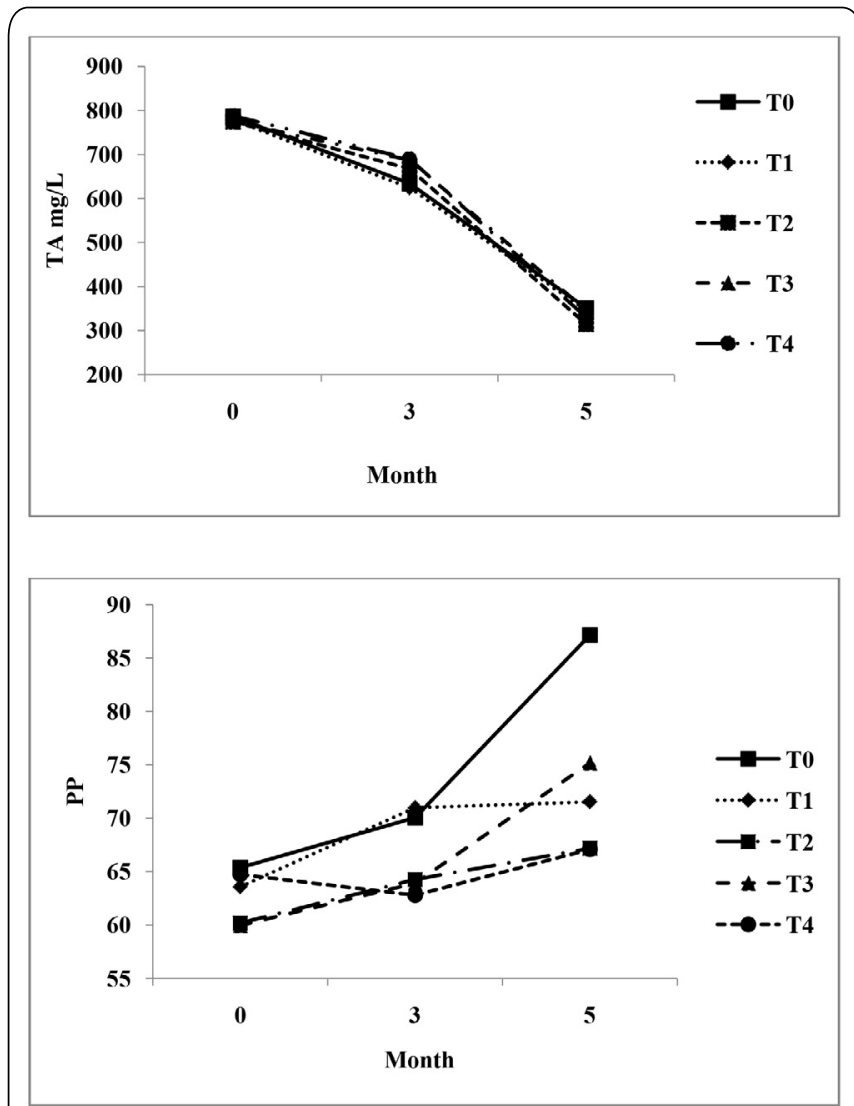

Figure 1: Evolution of total anthocyanins (TA) and polymerized pigments (PP) after five months of storage. $\mathrm{T}_{0}$ : Control; $\mathrm{T}_{1}$ : micro-oxygenation; $\mathrm{T}_{2}$ : Gelatin; $\mathrm{T}_{3}$ : polyvinylpolypyrrolidone based formulation; $\mathrm{T}_{4}$ : pea protein.

The result of sensorial analysis presented in Figure 3, showed that, all the different treatments had no significant impact on the variation of the color intensity during the two steps (bottling and the five months storage step). It was observed for all samples during the five months storage that there was a slight reduction of color intensity. This result is consistent with the change in the color intensity and redness $\left(a^{*}\right)$ measured by the spectrophotometer and CIElab (Table 1).

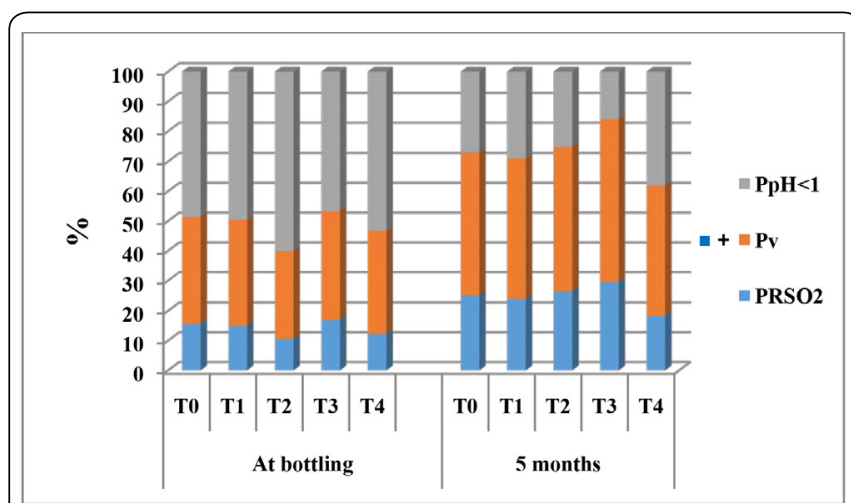

Figure 2: Chromatic characteristics and colour of micro-oxygenated and both fined/unfined red press wines at bottling and after five months of storage. $(\mathrm{PpH}<1)$ : total pigments at acidic $\mathrm{pH}$; $(\mathrm{PV})$ : wine pigments corrected of bisulphite at wine $\mathrm{pH}$; (PRSO2): sulphites bleaching resistant pigments; $\mathrm{T}_{0}$ : control; $\mathrm{T}_{1}$ : micro-oxygenation; $\mathrm{T}_{2}$ : gelatin; $\mathrm{T}_{3}$ : polyvinylpolypyrrolidone based formulation; $\mathrm{T}_{4}$ : pea protein.

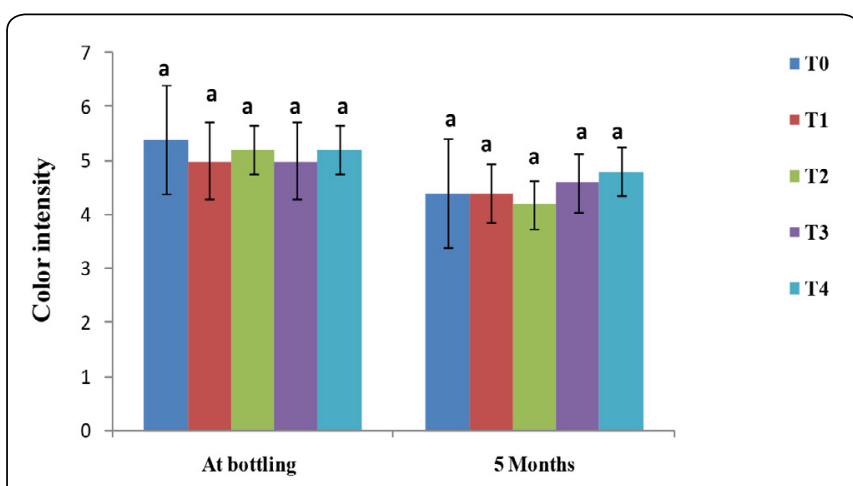

Figure 3: Sensorial colour intensity of micro-oxygenated and both fined/unfined red press wines at bottling and after five months of storage. Means followed by the same letter are not significantly different (LSD, 5\%). $\mathrm{T}_{0}$ : Control; $\mathrm{T}_{1}$ : micro-oxygenation; $\mathrm{T}_{2}$ : gelatin; $\mathrm{T}_{3}$ : polyvinylpolypyrrolidonebased formulation; $\mathrm{T}_{4}$ : peaprotein.

\section{Monomeric anthocyanins}

The monomeric anthocyanins identified with their retention time by HPLC are given in Table 2. At bottling, 
Table 2: Anthocyanin compounds identified with their retention time by HPLC-DAD analyses.

\begin{tabular}{|l|l|l|}
\hline Pic & Retention time (min) & Compound \\
\hline 1 & 39,68 & Delphinidine-3-O-glucoside \\
\hline 2 & 41,75 & Cyanidine-3-O-glucoside \\
\hline 3 & 43,79 & Petunidine-3-O-glucoside \\
\hline 4 & 45,56 & Peonidine-3-O-glucoside \\
\hline 5 & 47,33 & Malvidine-3-O-glucoside \\
\hline 6 & 48,99 & Delphinidine-3-O-acetylglucoside \\
\hline 7 & 49,88 & Cyanidine-3-O-acetylglucoside \\
\hline 8 & 52,36 & Petunidine-3-O-acetylglucoside \\
\hline 9 & 55,19 & Peonidine-3-O-acetylglucoside \\
\hline 10 & 56,72 & Malvidine-3-O-acetylglucoside \\
\hline 11 & 65,19 & Peonidine-3-O-coumaroylglucoside \\
\hline 12 & 65,67 & Malvidine-3-O-coumaroylglucoside \\
\hline
\end{tabular}

These results are corroborated by McCloskey and Yengoyan [5] who have shown that acylated monoglucoside pigments breakdown faster than the other monoglucosides in wine. A part of the monomeric anthocyanins is supposed to be gradually incorporated into polymeric pigments which confer color stability to the wine. This result showed that $\mathrm{PRSO}_{2}$ (pigments resistant to discoloration to sulfite) are increasing after five months of storage (Figure 2). The greatest decrease of malvidine-3-O-glucoside is conducted by both gelatin treatments $\left(\mathrm{T}_{2}\right)$ and basic PVPP formulation $\left(\mathrm{T}_{3}\right)$. The latter was coupled with bentonite. Several works [24] have described that the most remarkable effects on wine phenolic composition were produced by bentonite and gelatin, which significantly decreased anthocyanin and tannin concentrations respectively. Also the use of non-traditional fining agents, as vegetable proteins, may have less impact on the color and anthocyanin content of red wine.

Table 3: Influence of red press wine treatment on amount of monomeric anthocyanins (mean=SD) a-e: Means within a line followed by the same letter are not significantly different $(\mathrm{LSD}, 5 \%)(\mathrm{n}=2) . \mathrm{T}_{0}$ : control; $\mathrm{T}_{1}$ : micro-oxygenation; $\mathrm{T}_{2}$ : gelatin; $\mathrm{T}_{3}$ : polyvinylpolypyrrolidone based formulation; $\mathrm{T}_{4}$ : pea protein.

\begin{tabular}{|c|c|c|c|c|c|c|c|c|c|c|c|c|}
\hline \multirow{2}{*}{$\begin{array}{l}\text { Compound } \\
\mathrm{mg} / \mathrm{L}\end{array}$} & Sig & $\mathrm{T}_{0}$ & $\mathrm{~T}_{1}$ & $\mathrm{~T}_{2}$ & $\mathrm{~T}_{3}$ & $\mathrm{~T}_{4}$ & Sig & $\mathrm{T}_{0}$ & $\mathrm{~T}_{1}$ & $\mathrm{~T}_{2}$ & $\mathrm{~T}_{3}$ & $\mathrm{~T}_{4}$ \\
\hline & & & At bottling & & & & & & 5 months & & & \\
\hline Del-3-glu & $* *$ & $13.48 \pm 0.20^{\mathrm{a}}$ & $13.56 \pm 0.21^{a}$ & $13.75 \pm 0.20^{\mathrm{ab}}$ & $14.57 \pm 0.10 \mathrm{~b}^{\mathrm{b}}$ & $14.67 \pm 0.21^{b}$ & $* *$ & $7.34 \pm 0.15^{b}$ & $7.77 \pm 0.91^{\mathrm{bc}}$ & $7.19 \pm 0.77^{\mathrm{ab}}$ & $6.40 \pm 0.11^{\mathrm{a}}$ & $8.44 \pm 0.13^{c}$ \\
\hline Cya-3-glu & n.s & $1.58 \pm 0.19^{\mathrm{a}}$ & $1.38 \pm 0.15^{\mathrm{a}}$ & $1.29 \pm 0.23^{\mathrm{a}}$ & $1.65 \pm 0.18^{\mathrm{a}}$ & $1.65 \pm 0.21^{\mathrm{a}}$ & n.s & $1.37 \pm 0.54^{a}$ & $1.16 \pm 0.20^{\mathrm{a}}$ & $1.24 \pm 0.65^{\mathrm{a}}$ & $1.30 \pm 0.45^{\mathrm{a}}$ & $1.29 \pm 0.20^{\mathrm{a}}$ \\
\hline Pet-3-glu & $*$ & $16.63 \pm 0.21^{\mathrm{a}}$ & $16.55 \pm 0.12^{\mathrm{a}}$ & $16.65 \pm 0.30^{\mathrm{a}}$ & $18.75 \pm 0.21^{\mathrm{c}}$ & $17.55 \pm 0.20^{\mathbf{b}}$ & **** & $7.62 \pm 0.25^{\mathrm{a}}$ & $8.11 \pm 0.21^{b}$ & $0.18^{b}$ & $6.27 \pm 0.23^{\mathrm{a}}$ & $9.15 \pm 0.51^{c}$ \\
\hline Peo-3-glu & $*$ & $6.14 \pm 0.18^{\mathrm{a}}$ & $6.97 \pm 0.31^{b}$ & $6.60 \pm 0.15^{\mathrm{ab}}$ & $7.70 \pm 0.20^{c}$ & $6.80 \pm 0.20^{b}$ & n.s & $0.72 \pm 0.22^{\mathrm{a}}$ & $0.66 \pm 0.20^{\mathrm{a}}$ & $0.63 \pm 0.21^{\mathrm{a}}$ & $0.55 \pm 0.16^{\mathrm{a}}$ & $0.68 \pm 0.11^{a}$ \\
\hline Mal-3-glu & $* * *$ & $139.33 \pm 1.1^{\mathrm{a}}$ & $138.55 \pm 0.97^{\mathrm{a}}$ & $142.75 \pm 0.56^{\mathrm{b}}$ & $153.25 \pm 0.64^{d}$ & $148.65 \pm 0.43^{c}$ & **** & $77.15 \pm 0.91^{\mathrm{c}}$ & $83.85 \pm 1.19^{d}$ & $75.75 \pm 0.51^{b}$ & $64.95 \pm 0.81^{a}$ & $94.75 \pm 0.96^{\mathrm{e}}$ \\
\hline Del-3-ac & $*$ & $8.40 \pm 0.20^{\mathrm{a}}$ & $7.99 \pm 0.14^{\mathrm{a}}$ & $9.74 \pm 0.21^{\mathrm{c}}$ & $9.01 \pm 0.70^{\mathrm{b}}$ & $9.78 \pm 0.25^{\mathrm{c}}$ & ---- & n.d & n.d & n.d & n.d & n.d \\
\hline Cya-3-ac & *** & $5.00 \pm 0.11^{a}$ & $5.01 \pm 0.10^{\mathrm{a}}$ & $8.90 \pm 0.23^{b}$ & $8.76 \pm 0.35^{b}$ & $9.02 \pm 0.61^{b}$ & ---- & n.d & n.d & n.d & n.d & n.d \\
\hline Pet-3-ac & n.s & $5.26 \pm 0.31^{\mathrm{a}}$ & $5.21 \pm 0.51^{\mathrm{a}}$ & $5.24 \pm 0.21^{\mathrm{a}}$ & $5.07 \pm 0.18^{\mathrm{a}}$ & $5.27 \pm$ & --- & n.d & n.d & n.d & n.d & n.d \\
\hline Peo-3-ac & * & $3.07 \pm 0.41^{\mathrm{ab}}$ & $3.23 \pm 0.41^{b}$ & $2.73 \pm 0.50^{\mathrm{ab}}$ & $2.91 \pm 0.34^{\text {ad }}$ & $2.37 \pm 0.65^{\mathrm{a}}$ & $*$ & $1.56 \pm 0.13^{\mathrm{a}}$ & $1.70 \pm 0.21^{b}$ & $2.30 \pm 0.19^{\mathrm{ab}}$ & $2.80 \pm 0.18^{c}$ & $2.27 \pm 0.21^{\mathrm{ab}}$ \\
\hline Mal-3-ac & $* * *$ & $32.69 \pm 0.53^{c}$ & $34.85 \pm 0.21^{\mathrm{d}}$ & $30.15 \pm 0.20^{b}$ & $26.75 \pm 0.32^{a}$ & $34.95 \pm 0.41^{\mathrm{d}}$ & ns & $4.04 \pm 0.40^{a}$ & $3.87 \pm 0.47^{\mathrm{a}}$ & $3.82 \pm 0.35^{\mathrm{a}}$ & $3.71 \pm 0.41^{\mathrm{a}}$ & $3.81 \pm 0.65^{\mathrm{a}}$ \\
\hline Peo-3-cou & n.s & $2.14 \pm 0.2^{\mathrm{a}}$ & $1.78 \pm 0.61^{\mathrm{a}}$ & $1.60 \pm 0.21^{\mathrm{a}}$ & $1.13 \pm 0.20^{\mathrm{a}}$ & $1.93 \pm 0.21^{\mathrm{a}}$ & ---- & n.d & n.d & n.d & n.d & n.d \\
\hline Mal-3-cou & $* * *$ & $17.13 \pm 0.13^{c}$ & $18.85 \pm 0.46^{\mathrm{d}}$ & $16.05 \pm 0.51^{b}$ & $13.35 \pm 0.10^{\mathrm{a}}$ & $21.15 \pm 0.17^{\mathrm{d}}$ & $*$ & $2.59 \pm 0.91^{\mathrm{ab}}$ & $2.13 \pm 0.51^{a}$ & $2.83 \pm 0.61^{\mathrm{ab}}$ & $3.16 \pm 0.41^{\mathrm{c}}$ & $2.73 \pm 0.56^{a b}$ \\
\hline Total & $*$ & $250.85 \pm 3.35^{\mathrm{a}}$ & $253.95 \pm 4.2^{\mathrm{a}}$ & $255.47 \pm 3.51^{\mathrm{a}}$ & $262.91 \pm 3.52^{2 \mathrm{~b}}$ & $273.81 \pm 3.75^{\mathrm{b}}$ & $* *$ & $102.4 \pm 3.51^{\mathrm{b}}$ & $109.2 \pm 3.90^{c}$ & $101 \pm 3.47^{\mathrm{b}}$ & $89.15 \pm 2.76^{\mathrm{a}}$ & $123.13 \pm 3.3^{\mathrm{d}}$ \\
\hline
\end{tabular}

n.s: no significant ( $>0.05)$; significant levels: *: $\mathrm{p}<0.05$; **: $\mathrm{p}<0.01$; ${ }^{* * *}: \mathrm{p}<0.001$; n.d: means not detected; Del-3-glu: Delphinidine-3-O-glucoside; Cya3-glu: Cyanidine-3-O-glucoside; Pet-3-glu: Petunidine-3-O-glucoside; Peo-3-glu: Peonidine-3-O-glucoside; Mal-3-glu: Malvidine-3-O-glucoside; Anthocyanidin-3-ac: Anthocyanidin-3-O-acetylglucoside; Anthocyanidin-3-cou: Anthocyanidin-3-O-coumaroylglucoside.

the amount of malvidine-3-O-acetylglucoside and malvidine3-O-coumaroylglucoside were lowered by both fining agents: gelatin $\left(\mathrm{T}_{2}\right)$ and PVPP based formulation $\left(\mathrm{T}_{3}\right)$ (Table 3 ). However, this amount was increased by the micro-oxygenation and pea protein fining agent $\left(\mathrm{T}_{4}\right)$. The glucoside derivative remained higher than control wine after the addition of the fining agents. Several works have shown that isinglass's and gelatin had the least effect on total monomeric anthocyanin amount, while the highest effect was observed by casein and potassium caseinate [23]. After five months of wine storage, the most stable anthocyanins were those containing glucoside derivatives, while the amounts of acylated and coumaroylated anthocyanins were considerably decreased.

\section{Conclusion}

This study reveals that all fining agent used (liquid gelatin, fining agent based on PVPP and pea protein) allow a good clarification of the Moroccan treated press wine in comparison with the untreated one. Each treatment has a distinct behavior on chromatic characteristics and anthocyanins composition, affecting both the monomers and the polymeric pigment. All fining agents decreased the pigmentation significantly. Fining agent PVPP based formulation seemed to eliminate more color. However, the micro-oxygenated press wine was more colored. On the sensory quality plan, the press wine remained very colored and its color is not altered by all treatments. 


\section{Acknowledgments}

Thanks are addressed to Frederic Veran for supervising analysis and helpful discussion and to The Agence Universitaire de la Francophonie (AUF) for their assistance.

\section{Conflict of Interest}

The authors declare no conflict of interest.

\section{References}

1. Morge C. 2011. The stabilization of the coloring matter of red wines: positive impact adding a tannin " $100 \%$ grape" low degree of polymerization (average polymerization degree or $\mathrm{Dpm} \leq 3$ ). French Journal of Oenology 248.

2. Atanasova V, Fulcrand H, Cheynier V, Moutounet M. 2002. Effect of oxygenation on polyphenol changes occurring in the course of winemaking. Anal Chim Acta 458(1): 15-27. https://doi.org/10.1016/S00032670(01)01617-8

3. Fulcrand H, Cameira-dos-Santos PJ, Sarni-Manchado P, Cheynier V, Favre-Bonvin J. 1996. Structure of new anthocyanin-derived wine pigments. J Chem Soc Perkin 1: 735-739. https://doi.org/10.1039/ P19960000735

4. Es-Safi N, Le Guenervé C, Cheynier V, Moutounet M. 2000. New phenolic compounds obtained by evolution of $(+)$-catechin and glyoxylic acid in hydroalcoholic medium. Tetrahedron Lett 41(12): 1917-1921. https://doi.org/10.1016/S0040-4039(00)00043-5

5. Mccloskey LP, Yengoyan LS. 1981. Analysis of anthocyanins in Vitis vinifera wines and red color versus aging by HPLC and spectrophotometry high pressure liquid chromatography. Am J Enol Vitic 32: 257-261.

6. Brouillard R. 1988. Flavonoids and flower colour. In: Harborne JB (ed) The flavonoids. advances in research since 1980. Chapman and Hall, London, UK, pp 525-538. https://doi.org/10.1007/978-1-4899-29136_16

7. Ribéreau-Gayon P, Glories Y, Maujean A, Dubourdieu D. 1998. Phenolic compounds. In: Handbook of enology volume 2 the chemistry of wine stabilization and treatments $2^{\text {nd }}$ edition. John Wiley and Sons Ltd, UK, pp 141-204. https://doi.org/10.1002/0470010398

8. Vivas N. 2007. Les composés phénoliques et lélaboration des vins rouges. Edition Féret, Bordeaux, France.

9. Renouf V, Murat ML. 2012. La valorisation des vins de presse par un collage précoce et approprié. La revue française d'œnologie 142: 32-35.

10. Chagas R, Monteiro S, Ferreira RB. 2012. Assessment of potential effects of common fining agents used for white wine protein stabilization. Am JEnol Vitic 63: 574-578. https://doi.org/10.5344/ajev.2012.12016
11. Gómez-Plaza E, Gil-Muñoz R, López-Roca JM. Martinez A. 2000. Color and phenolic compounds of a young red wine. Influence of wine making techniques, storage temperature and length of storage time. $J$ Agric Food Chem 48(3): 736-741. https://doi.org/10.1021/jf9902548

12. Lesica M, Kosmerl T. 2009. Microoxygenation of red wines. Acta Agric Slov 93(3): 327-336.

13. Granato TM, Piano F, Nasi A, Ferranti P, Iametti S, et al. 2010. Molecular basis of the interaction between proteins of plant origin and proanthocyanidins in a model wine system. J Agric Food Chem 58(22): 11969-11976. https://doi.org/10.1021/jf102603r

14. Cheynier V, Duenas M, Salas E, Maury C, Souquet J, et al. 2006. Structure and properties of wine pigments and tannins. Am JEnol Vitic 57: 298-305.

15. Aziz MB, Mouls L, Fulcrand H, Douieb H, Hajjaj H. 2017. Phenolic compounds of Moroccan red press wines: Influence of fining agents and micro-oxygenation treatments. LWT-Food Science and Technology 78: 143-150. https://doi.org/10.1016/j.lwt.2016.12.034

16. Glories Y. 1984. The red wines color. Part 2 Origin and Interpretation. Connaissance de la vigne et du vin 18: 253-271.

17. Ribereau-Gayon P, Stonestreet J. 1965. The dosage of anthocyanins in red wine. Bull Society of Chimica 9: 2649-2652.

18. Ducasse MA. 2009. Impact of maceration enzymes on the composition of polysaccharides and polyphenols of red wines Study of the evolution of these compounds in solution model, Ph.D Thesis, Montpellier University II, France.

19. Gil-Muñoz R, Gómez-Plaza E, Martínez A, López-Roca JM. 1997. Evolution of the CIElab and other spectrophotometric parameters during wine fermentation. Influence of some pre and post fermentative factors. Food Res Int 30(9): 699-705. https://doi.org/10.1016/S09639969(98)00029-5

20. Siebert KJ, Troukhanova NV, Lynn PY. 1996. Nature of polyphenolprotein interactions. J Agric Food Chem 44(1): 80-85. https://doi. org/10.1021/jf9502459

21. Wirth J, Caillé S, Souquet JM, Samson A, Dieval JB, et al. 2012. Impact of post-bottling oxygen exposure on the sensory characteristics and phenolic composition of Grenache rosé wines. Food Chem 132(4): 18611871. https://doi.org/10.1016/j.foodchem.2011.12.019

22. Boulton R. 2001. The copigmentation of anthocyanins and its role in the colour of red wine: a critical review. Am J Enol Vitic 52: 67-87.

23. Cosme F, Ricardo-da-Silva JM, Laureano O. 2008. Interactions between protein fining agents and proanthocyanidins in white wine. Food Chem 106(2): 536-544. https://doi.org/10.1016/j.foodchem.2007.06.038

24. González-Neves G, Favre G, Gil G. 2014. Effect of fining on the colour and pigment composition of young red wines. Food Chem 157(15): 385392. https://doi.org/10.1016/j.foodchem.2014.02.062 